\title{
The Russian Revolutions of 1917: The Northern Impact and Beyond
}

\author{
Kari Aga Myklebost, Jens Petter Nielsen \& Andrei Rogatchevski (red.) \\ Boston: Academic Studies Press 2020 \\ 211 pages. ISBN: 9781644690642
}

\begin{abstract}
Omtalt af Erik Kulavig [lektor emeritus ved Syddansk Universitet, kulavig@, sdu.dk]
\end{abstract}

Det er ikke ligegyldigt, hvad man kalder historiske begivenheder, og derfor var det måske på tide at finde nogle andre betegnelser for de to begivenheder, der fandt sted i Rusland i henholdsvis februar og oktober 1917. I denne bog taler man om revolutioner, men det var det jo strengt taget ikke. Tsarens abdikation og dannelsen af den provisoriske regering i februar var ikke en borgerlig revolution, som man ofte har villet gøre den til. Det havde, som Lenin rigtigt skriver, krævet et langt større, mere handlekraftigt, modigt og sammentømret borgerskab. Lenins og Trotskijs magtovertagelse i oktober var en blanding af et traditionelt bondeoprør og et statskup.

Det diskuteres af gode grunde ikke i den foreliggende bog, for det er ikke selve de to begivenheder, der er i centrum, men deres betydning for "det høje nord", der i dette tilfælde hovedsageligt omfatter det nordlige Rusland og den nordlige del af nabolandet Norge. Der er også et par afstikkere til andre steder herunder Oslo og Sverige og Paris, hvilket markeres i bogens titel med: »and beyond«. Så er det på plads.

Den direkte anledning til bogen var en konference med samme titel, der i oktober 2017 blev afholdt på UiT, The Artic University of Norway, der også er kendt som Universitetet i Tromsø. Her er der en lang tradition for gode forbindelser til Universitetet i Arkhangelsk, og det er derfor ikke noget tilfælde, at det store flertal af de 13 bidragsydere kommer fra disse to institutioner. Der er således i mere end en forstand tale om lokalhistorie eller regionalhistorie. Det er ikke ment nedsættende, men man bemærker alligevel, at de regionalt placerede forfattere er bevidste om, at de repræsenterer en geografisk udkant, som, de ikke desto mindre mener, fortjener meget mere opmærksomhed, end den får. Det bekræftes af mange af artiklerne.

Blandt bidragsyderne er der flere kendte navne og garvede Ruslands-historikere som nordmændene Åsmund Egge (Oslo) og Jens Petter Nielsen (Tromsø), svenskeren Klas-Göran Karlsson (Lund) og Catherina Andreyev (Oxford). Fra Arkhangelsk skal nævnes professor Vladislav Ivanovich Golding, der er noteret for ikke mindre end 530 publicerede akademiske værker. 
Catherina Andreyev tager i artiklen: »1917: The Evolution of Russian Émigré Views of the Revolution " tråden op fra sin mangeårige forskning i russiske emigrantmiljøer og fortæller om, hvordan perceptionen af "1917 « har ændret sig med tiden. Forfatteren er utvivlsomt godt inde i emnet, men teksten er relativt kort og noget ufokuseret og derfor vanskelig at gå til for lægmand.

Åslund Egge lægger i sit bidrag: "Soviet Diplomacy in Norway and Sweden in the Interwar Years: the Role of Alexandra Kollontai« ikke skjul på, at han er fascineret af samme Kollontaj, der var feminist, medlem af Lenins første regering og Stalins udsendte i Norge og Sverige i mellemkrigstiden. Når forfatteren giver hende bedømmelsen "en fremragende diplomat", er det, fordi hun havde evnen og måske navnlig modet til at fortælle Stalin om tingene, som de var i de to lande, og ikke blot som de burde være. Stalin var meget bevidst om, at hans meddelere foretrak at fortælle ham, hvad de troede, han gerne ville vide, i stedet for fakta, så han har sikkert sat pris på Kollontaj.

Vladislav Golding har bidraget med en forskningsoversigt over revolutionen og den russiske borgerkrig i nord, hvor han understreger, at borgerkrigen var et yderst sammensat og komplekst fænomen, der rakte langt videre end til kampen mellem "de røde" og »de hvide». Han antyder, at de britiske styrkers ankomst til Arkhangelsk i 1918 og deres støtte til de antibolsjevistiske kræfter giver dem et betydeligt medansvar for borgerkrigens udvikling i »det høje nord «. Da briterne forlod området, var det en smal sag for "de røde" at slå de "hvide» hjem.

Klas-Göran Karlsson giver en veloplagt prøve på sine historiemetodiske færdigheder i artiklen: „The Russian Revolution in Sweden: Some Genetic and Genealogical Perspectives". Her demonstreres det sort på hvidt, hvordan historien om især bolsjevikkerne er blevet brugt og navnlig misbrugt i personlige og politiske ærinder, og hvordan perceptionen desuden forandres med tidernes skiften.

Ekaterina Kotlova og Tatiana Troshina tager fat på det økonomiske kaos, der breder sig som følge af revolutionen. Det er navnlig spørgsmålet om ejendomsretten, eller rettere bolsjevikkernes ophævelse af den private ejendomsret, der optager dem. Man får en klar fornemmelse af, at forfatterne har været langt nede i arkiverne. Som når de fortæller, at lokale russiske fiskere ikke var meget for at sælge deres fangst til de norske købmænd, fordi de angiveligt var bange for, at fisken skulle havne i fjendehænder. Det var næppe den egentlige årsag, men den var ideologisk rigtig. Gad vide, hvad de egentlig gik efter? Eller når de følger nogle nordmænd, der griber til selvtægt og om natten sejler ind til de gamle handelspladser og fjerner det udstyr og andet, som de (sikkert med rette) mente tilhørte dem.

Kari Aga Myklebost skriver veloplagt om den første norske professor i slavisk, den navnkundige Olaf Broch, og hans betydelige rolle som nordmændenes kilde til information om den russiske revolution. Han var en stor fan af den "borgerlige revolution", der skulle bringe Rusland ind i Europa, men måtte jo hurtigt indse, at der mere havde været tale om whishful thinking end om en solid analyse. 
Jens Petter Nielsen kæmper i sit indsigtsfulde bidrag med Putins problem med på den ene side at samle Rusland under, hvad han forstår som den russiske traditions stærke statsmagt, og samtidig erkende, at det altså lykkedes bolsjevikkerne at vælte statsmagten. Han kunne selvfølgelig som kommunisterne hævde, at bolsjevikkerne og ikke mindst Stalin var russisk tradition "med andre midler", men det er han foreløbig veget tilbage fra.

Ekaterina Rogachevskaia, der er kurator for den central- og østeuropæiske samling på British Library, bidrager med sine oplevelser fra bibliotekets udstilling: "Russian Revolution: Hope, Tragedy, Myth" (2017) som hun stod for. Interessante overvejelser om, hvad der skulle med, hvordan det skulle placeres, hvad der skulle stå i teksterne og ikke mindst om, hvad man kunne forvente, at publikum allerede vidste. I oplæg og stil stikker artiklen imidlertid noget ud fra de øvrige.

Andrei Rogatchevski, der er litterat og kulturforsker i Tromsø, tager os bort fra det norsk-russiske grænseland til det nordlige Ural, hvor bolsjevikkerne efter nogen tøven greb til efterhånden særdeles hårdhændede metoder for at tvinge de lokale fangere og fiskere til at sende deres børn i skole og ikke mindst tale bolsjevistisk. Det førte til en omfattende opstand i begyndelsen af trediverne, men den blev til sidst slået ned med anvendelse af militær og sågar luftvåben. Forfatteren har fokus på en moderne filmisk bearbejdning af dette drama. Han har mange fine pointer, hvad angår de krumspring, man må gøre for at få det hele "ned på lærredet", men desværre fuser et ellers spændende - måske samlingens bedste - kapitel ud i for mange filmnørdiske spekulationer.

Ole Martin Rønning er direktør for arbejderbevægelsens Arkiv og Bibliotek i Oslo og har skrevet ph.d.-afhandling om "Stalins elever». Her bidrager han med en artikel om Kominterns uddannelsesinstitutioner i kommunismens Mekka, Moskva i den første periode frem til den anden verdenskrig. Det er en spændende beretning, men læseren sidder ikke desto mindre tilbage med en vis tvivl om, om det nu også holder, at de skandinaviske studerende skulle have overtaget det sovjetiske verdenssyn efter et halvt eller to års ophold i Moskva. At dømme efter det sovjetiske hemmelige politis rapporter, som forfatteren selv har set, og hvor der står, at selv om de vestlige studerende drak for meget, var de ikke sådan lige til at få til at makke ret. For det samme taler det forhold, at de ikke umiddelbart lod sig lokke med i den "socialistiske kappestrid", der var kendt fra femårsplanerne.

Victoria V. Tevlina skriver om russisk immigration til Norge hen over den norsk-russiske grænse og med båd til norske havne i 1917 og under borgerkrigen. Der var overvejende tale om folk fra middelklassen og de højere lag, men der var ikke særligt mange af dem, og de fleste søgte videre til de store russerbyer som Berlin og navnlig Paris. Nogle blev dog, men måtte tage arbejde under deres stand. Andre eller deres efterkommere fik et navn i Norge.

Hallvard Tjelmeland, der er professor i det tyvende århundredes historie iTromsø med speciale i arbejderhistorie og den kolde krig, skriver om Oktoberrevolutionens 
indflydelse på den nordnorske arbejderbevægelse. Han gør gældende, at dele af den, allerede før inspirationen kom fra Øst, var betydeligt radikaliseret. Forfatteren forklarer det med de tydelige og kontante klassemodsætninger mellem fattige fiskere og forholdsvis velstående mellemhandlere. Derfor var der i arbejderkredse i Nordnorge større og bredere sympati for bolsjevikkerne end i det øvrige Norden. Det forklarer vel også, at man skal helt frem til engang i halvtredserne, før de norske socialdemokrater fjerner ideen om proletariatets diktatur fra partiprogrammet.

Vi kan altså slutte, at der er tale om en pose blandede bolsjer, hvoraf nogle er velsmagende og måske sågar nærende, mens man godt kunne være andre foruden. Jeg deler dog fuldt og helt "lokalhistorikernes" insisteren på, at "det høje nord" er værd at beskæftige sig med, fordi det ér noget særligt. Her har russere og nordmænd levet dør om dør i århundrede, og det giver en særlig forståelse for hinanden, som der måske i disse tider, hvor der er fuld gang i produktionen af fjendebilleder i Øst og Vest, er mere brug for end nogensinde før. 